\title{
Programmatic Re-Evaluation of Ion Exchange as a 1st Generation ITP Replacement
}

by

\author{
A. B. Scott \\ Westinghouse Savannah River Company \\ Savannah River Site \\ Aiken, South Carolina 29808
}

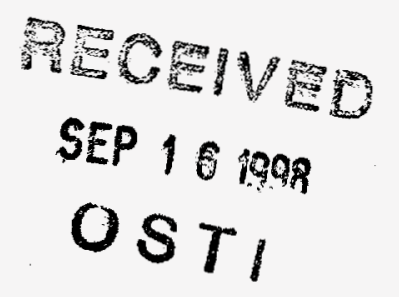

\section{MASTERYW"}

\section{DHOTAIBUTHON OF THS DOCUMET \& LAMUTED}

This paper was prepared in connection with work done under the above contract number with the $U$. S.

Department of Energy. By acceptance of this paper, the publisher and/or recipient acknowledges the U. S. Government's right to retain a nonexclusive, royalty-free license in and to any copyright covering this paper, along with the right to reproduce and to authorize others to reproduce all or part of the copyrighted paper. 


\section{DISCLAIMER}

This report was prepared as an account of work sponsored by an agency of the United States Government. Neither the United States Government nor any agency thereof, nor any of their employees, makes any warranty, express or implied, or assumes any legal liability or responsibility for the accuracy, completeness, or usefulness of any information, apparatus, product, or process disclosed, or represents that its use would not infringe privately owned rights. Reference herein to any specific commercial product, process, or service by trade name, trademark, manufacturer, or otherwise does not necessarily constitute or imply its endorsement, recommendation, or favoring by the United States Government or any agency thereof. The views and opinions of authors expressed herein do not necessarily state or reflect those of the United States Government or any agency thereof. 


\section{DISCLAIMER}

Portions of this document may be illegible in electronic image products. Images are produced from the best available original document. 
Letter, A. B. Scott, Jr. to S. D. Richardson, 11/15/93, HLW-OVP-930055

CC: DOE-SR
A. L. Watkins, 703-A
C. W. Terrell, 704-S
R. Schepens, 703-H
C. E. Anderson, 703-S
H. B. Gnann, 704-S
M. R. Jump, 704-S
M. G. Schwenker, 703-H
J. C. Truelove, 704-S
WSRC
C. L. Peckinpaugh, 719-4A
L. M. Papouchado, 773-A
S. S. Cathey, 703-H
F. F. Cadek, 719-4A
G. T. Wright, 703-H
D. B. Amerine, 704-S
W. B. Boore, 703-H
J. P. Morin, 719-4A
T. E. Pate, 742-12G 
Westinghouse

Savannah River Company
A. B. Scott, Jr.

Vico President and General Manager

High Level Wasto Management Division
P. O. Box 616

Aken, SC 29802

HLW-OVP-930055

November 15, 1993

Mr. Steven D. Richardson, Assistant Manager

High Level Waste

U. S Department of Energy

Savannah River Operations Office

P. O. Box A

Aiken, SC 29802

Dear Mr. Richardson

\section{PROGRAMMATIC RE-EVALUATION OF ION EXCHANGE AS A 1ST GENERATION ITP REPLACEMENT (U)}

Ref: (1) Letter, N. C. Boyter to L. C. Sjostrom, September 15, 1992, WSRC Evaluation of Ion Exchange as a Pretreatment Process for DWPF.

(2) Letter, L. C. Sjostrom to N. C. Boyter, December 21, 1992, WSRC Evaluation of Ion Exchange as a Pretreatment Process for Defense Waste Processing Facility.

(3) Presentation, W. B. Boore to A. L. Watkins, January 21, 1993.

Reference 1 was a programmatic evaluation prepared by a task team lead by W. B. Boore that concluded that In-Tank Precipitation (ITP)/Late Wash was the preferred technology for processing salt waste in support of the HLW Mission. This conclusion was based on the time required to implement a new Ion Exchange project, the cost of such a project and the lack of available tank space in the Tank Farm. The evaluation also concluded that early operation of ITP and Late Wash was the best means of supporting a future Ion Exchange project.

Reference 2 requested WSRC to re-evaluate Ion Exchange as a first generation ITP replacement using a somewhat different set of assumptions developed by DOE-SR that were more aggressive, success oriented but not unreasonable as 
S. D. Richardson

HLW-OVP-930055

Page 2

November 15, 1993

outlined in the letter. WSRC responded with a detailed presentation, reference 3 , based on the prescribed assumptions and concluded by reiterating the results of the original evaluation (reference 1).

It is my understanding that DOE-SR considers the issue of Ion Exchange as a first generation replacement for ITP to remain an open issue. The reevaluation attached to this letter is an additional look at the programmatic issues involved with implementing Ion Exchange in lieu of ITP. The conclusion and recommended course of action is similar to previous evaluations. The intent of this letter is to close this issue to allow us to focus our management and technical resources on the startup of ITP and DWPF with continued development of Ion Exchange as a second generation ITP replacement as well as other waste volume reduction technologies.

This re-evaluation differs from previous work in that 1) the Ion Exchange option was evaluated from a standpoint assuming that ITP would never start up, thus Ion Exchange was the only viable option, 2) the DOE prescribed balanced assumptions were quite different than the WSRC assumptions used previously, and 3) other Site events and changes within HLWM have tended to reduce the disadvantages of Ion Exchange relative to ITP as the first generation salt decontamination process. As an example of the latter, the difference in the time required to remove waste from old-style tanks using Ion Exchange versus ITP is minimal due to reduced EM funding projections. Also, there is a series of actions, expenditures and successful technical evaluations outlined in this re-evaluation that could enable the Tank Farm to support an early sludge-only DWPF startup as well as the currently planned SRS production mission while maintaining Tank Farm operations until such time as an Ion Exchange facility could start up in hot operations.

As in the previous evaluations, the Ion Exchange (IX) option involves more programmatic risk than ITP primarily because salt processing is delayed for several years during a time of great uncertainty in the Site mission. If IX is the chosen option, then the Tank Farm would be at maximum salt storage capacity with very little margin for receiving and storing liquid waste. ITP remains the WSRC recommendation for salt processing for three compelling reasons: 1) DX and the actions required to make it viable could be an additional cost of up to $\$ 500,000,000$ to the EM program at a time when the EM funding may be reduced, 2) choosing the IX option delays the ability for the Tank Farm to support future Site missions above those currently planned, and 3) the ITP flowsheet has been developed and tested in full scale radioactive demonstrations as opposed to the IX option which may contain unknown process problems. 
S. D. Richardson

HLW-OVP-930055

Page 3

November 15, 1993

Note that HLWM recommends continued IX process development in support of Oak Ridge, Hanford and the SRS ITP second generation missions and as a potential process to reduce the volume of the Extended Sludge Processing and DWPF recycle streams. SRS funding in the amount of $\$ 2,000,000$ has been allocated to this effort in FY94. Additional funding from the Office of Technology and Development has also been committed. HLWM has established Jerome P. Morin from HLWM Engineering to coordinate the IX program and serve as a single point of contact to provide improved management focus.

We welcome the opportunity to review this re-evaluation with you and your staff at your convenience. Please direct your questions or concerns to me or $\mathrm{S}$. S. Cathey at 5-3052.

Sincerely,

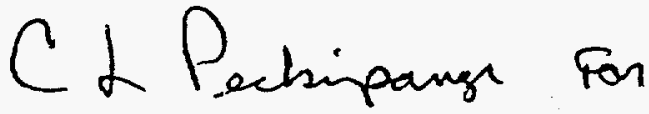

A. B. Scott, Jr.

Vice President and General Manager

High Level Waste Management Division

$\mathrm{NRD} / \mathrm{nrd}$

Att. 


\section{PROGRAMMATIC RE-EVALUATION OF IX AS A 1ST GENERATION ITP REPLACEMENT}

\section{Initial DOE-SR Assumptions}

Reference 2 outlined six assumptions that were to be used as a basis for the programmatic re-evaluation. Each assumption is listed below. Table 1 repeats each assumption followed by our interpretation of the effect (i.e. degree of constraint or degree of freedom) each assumption affords this reevaluation.

- In-Tank Precipitation (ITP) will not be available and salt decontamination will be done exclusively using IX.

- Existing structure(s) (e.g., ITP Filter Cells, Auxiliary Pump Pit, Salt Processing Cell, New Waste Transfer Facility or any combination thereof) will be used for IX to the maximum possible extent.

- Known techniques for manipulating the radioactivity and resins, (e.g., eluting cesium from the Savannah River Site resorcinol/formaldehyde resin with nitric acid, removing strontium and plutonium with monosodium titanate) are to be used.

- IX implementation can be done within the scope of an existing project or the best possible alternate path should be identified (i.e., accelerated project authorization).

- IX implementation will be coordinated to meet the earliest startup date for DWPF while maximizing retention of Tank Farm space.

- Additional research and development should be minimized and accelerated to the extent possible.

\section{Initial WSRC Assumptions}

There are additional assumptions that must be listed as they are equally important to this re-evaluation as those listed above. They are:

- There will be no new large (on the order of $1,000,000$ gallon capacity) waste tanks built at SRS.

- The existing Site missions will be supported, i.e., removing waste from tanks and the Separations Phaseout and Stabilization programs.

- There will be no new Site missions, such as Canyon or Reactor D\&D or Separations processing of offsite fuels, that generate significantly more waste than what is currently forecast. 
- The Canyons will continue to evaporate miscellaneous streams after the Phaseout and Stabilization programs are complete until such time as HLWM can assume this additional load, i.e. until the RHLWE starts up.

- DWPF will start up on sludge-only and continue to operate at low attainment until IX is ready to be tied-in.

- Sludge batch \#2 will be washed before IX starts up to enable the feed to DWPF to be continuous.

- Sludge and salt processing operations will start when sludge batch \#2 is ready to feed to DWPF.

- Tanks 2-8 (Type I Tanks with no known leaks) can be used as 1,300,000 gallons of emergency spare space for the F-Area Tank Farm in lieu of space in Type III Tanks.

- IX must be reasonably "de-coupled" from the Tank Farm and DWPF similar to ITP and ESP as they currently exist.

\section{Assumed IX Startup Date}

The next step is to roughly establish a reasonable startup date for an IX project. The term "roughly" is used because there is insufficient data available to develop a conceptual design, cost estimate and integrated schedule for IX at this time (this will be somewhat rectified by an ongoing Engineering Evaluation scheduled for completion in 1994). In this application, a rough date is acceptable because the bulk of the salt waste that must be handled by the Tank Farm is generated before the end of FY98 which means that the IX startup date, assuming that it is after FY98, has little effect on the condition of the Tank Farm. This will become evident later.

The assumed IX startup date used in this re-evaluation is FY 00 or six years from an assumed IX program start in FY94.

\section{Static Material Balance}

The next step is to attempt to establish a static material balance for the salt loading in the Tank Farm. The Tank Farm is currently more full of liquid waste and saltcake than at any time in the history of the Site. Starting up DWPF and ESP sludge washing operations aggravate this condition for the first several years of operation. In fact, if DWPF were ready to start up today, the Tank Farm could not support the startup because the Tank Farm is too full of unevaporated waste. The Tank Farm evaporators must operate for

one to one and a half years to recover enough space to support DWPF startup. Generating tank space to handle the DWPF and ESP waste streams will fill the remaining salt receipt tanks with saltcake as the Tank Farm is currently configured. 
Once the evaporators restart, the pinchpoint will shift from liquid waste storage to available salt receipt space. The planned salt generating operations are listed below:

- Evaporate the existing backlog of Low Heat Waste (LHW) and High Heat Waste (HHW) in the Tank Farm. There is currently a 7,000,000 gallon backlog of primarily HHW in the Tank Farm. The backlog has accumulated over a 4-5 year period while the $1 \mathrm{H}$ Evaporator was been down for hardware and Conduct of Operations upgrades. It is imperative to generate tank space by evaporation to provide receipt space for the DWPF recycle and ESP sludge batch \# 2 washwater streams. There must be adequate contingency tank space at the time DWPF goes hot because the recycle stream is not readily turned off or reduced below 1,000,000 gallons/yr from a high of 3,600,000 gallons/yr. Also, the ESP stream is generated in large batches of 350,000 to 950,000 gallons each.

- The ESP tanks currently contain the sludge that will comprise the first batch of sludge feed to DWPF. The batch is partially washed and will generate about $1,150,000$ gallons of washwater in three 350,000 gallon batches to complete the washing process.

- It is assumed that sludge batch \#1 will be consumed by DWPF in a prolonged sludge-only campaign ending when IX starts up. The washing of sludge batch \#2 must therefore occur prior to IX startup. This also ensures continuity of feed to DWPF.

- The Tank Farm will receive the waste from all currently planned Canyon operations and evaporate that waste into saltcake. Current missions are limited to only the stabilization program for each Canyon outlined in P\&PD 93-0 and ASD-NMP-93-0009 dated April 22, 1993.

- The Tank Farm will evaporate the DWPF recycle from the sludge-only campaign.

Execution of the above operations generates the saltcake shown below:

\section{Operation}

- evaporate existing backlog of HHW \& LHW

- complete sludge batch \#1 washing

- sludge batch \#2 washing prior to IX startup

- planned Canyon receipts

- evaporate DWPF recycle until IX startup

Total Equivalent Saltcake
Equivalent

Saltcake (gal)

$3,000,000$

300,000

800,000

$1,500,000$

300,000

$5,900,000$ 
The saltcake shown above would be generated before the end of FY98 with the exception of some of the sludge batch \#2 washing and DWPF recycle which would all be generated by FY00. There will be a period of time, about two years, after IX startup where the evaporators continue to generate salt before IX recovers salt receipt tanks. No reserve is set aside for this as the salt generation rate will be about 30,000 gallons per year until sludge batch \#3 washing starts. This is shown in Figure 2. By that time, IX will have recovered Tank 48 plus the first tank that can be reused as a salt receiver.

The available salt space as the Tank Farm as currently configured is listed below:

\begin{tabular}{cr}
$\begin{array}{cr}\text { Salt } \\
\text { Tank }\end{array} 2$ & Space \\
\hline 27 & 0 \\
30 & $1,000,000$ \\
38 & 100,000 \\
46 & $1,000,000$
\end{tabular}

$2,100,000$

\section{Notes}

Tank 27 contains $0.5 \mathrm{Mgal}$ of salt and $0.6 \mathrm{Mgal}$ of concentrated supernate currently contains fresh unevaporated HHW Tank 38 contains $0.6 \mathrm{Mgal}$ of salt and $0.3 \mathrm{Mgal}$ of concentrated supernate previously used as emergency spare tank, contains no salt

Total Salt Space Available

There is a shortfall of $3,800,000$ gallons of salt space as shown above assuming that ITP does not operate (ITP recovers salt space if it is operating) and assuming that Type III Tanks continue to be used as they are now. This means that more salt space in Type III Tanks is needed.

\section{Reuse of Existing Type III Tanks for IX}

The existing Type III Tanks must be evaluated to identify those that will be required to support IX before they can be evaluated for salt receipt service. Using existing tanks will ensure that the cost of $D X$ is kept to a minimum and that existing facilities are used to the maximum extent possible.

Significant piping and storage capacity will be required to effectively operate IX. The feed rate to IX will be about 1,500,000 gallons of saltcake per year dissolved in about 4,500,000 gallons of salt solution. About one half of this waste comes from F-Area to H-Area where IX will presumably be located. It is not feasible to feed IX directly from F-Area via the F/H Inter-Area Line (IAL) because the IAL and other line segments have many other uses and cannot be dedicated to IX. A large feed tank is therefore required to effectively de-couple IX from the Tank Farm. The large tank is assumed to be an existing $1,300,000$ 
gallon Type III waste tank in H-Area, Tank 48. Using an existing tank keeps the IX cost down. For purposes of this re-evaluation, it is assumed that Tank 48 can be filled with salt, be the first salt tank fed to IX, and then serve as the IX feed tank thereafter. There will be some IX attainment loss during the feeding of Tank 48 due to the salt dissolution process time required to lower slurry pumps, sample, inspect the tank interior, etc. This problem is diminished after Tank 48 is empty. In the long term, one IX feed tank is still not optimal but is thought to be acceptable.

IX will require a large decontaminated effluent receipt tank just as ITP requires a large filtrate storage tank. Tank 50 is planned to serve this function for ITP and it is assumed to fulfill the same function for IX. The decontaminated IX effluent and ETF evaporator bottoms will be stored in Tank 50 and fed to Saltstone.

IX will require a heavily shielded tank to receive the eluate and filter flushes. This tank does not necessarily have to be an existing Type III Tank if it acceptable to build a small tank. As an example, a tank with a 50,000 gallon working capacity could hold about 18 days of eluate and filter flushes assuming: a) that IX generates about 5,000 gallons of eluate every 86 hours at $100 \%$ attainment, and b) that flushwater is generated in equal proportion to eluate. There is no experimental basis for the latter assumption but it is thought to be conservative. The 50,000 gallon tank would fill much more slowly at reduced attainment rates, i.e. 72 days at $25 \%$ attainment which is about the attainment rate for the HLW System that is possible given the projected EM funding. A detailed attainment or utility analysis may conclude that a tank larger than 50,000 gallons or high IX throughput capability is needed to accommodate IX facility outages, etc., but the larger tank would still be small relative to a Type III tank.

\section{Potential Type III Tank Usage Assuming IX}

The next step is to evaluate all twenty-seven Type III Tanks for possible use as salt receipt tanks. Table 3 shows all Type III Tanks, the future use of each tank assuming that ITP does not start up, and any other considerations that may be necessary to change the currently planned use for each tank. A total of five tanks are identified in Table 3 as potential salt receivers.

The three tanks involved with ESP are assumed to remain in ESP service. The ESP operation could be conducted in two waste tanks but at a severe penalty in the amount of washwater generated and in the time required for washing.

Three of the five tanks that are currently in fresh HHW receipt service (Tarks 32,33 , and 35) could be redeployed as salt receipt tanks leaving one fresh 
HHW receiver in each area. This is not recommended by WSRC at this time; it is discussed in the context of this open minded re-evaluation. Keeping one fresh HHW receiver in each area keeps the option open for SRS to process fuel, albeit at a low rate, should the need arise. There is a significant technical issue when salt is formed above HHW sludge in a waste tank. The sludge generates hydrogen which could become trapped underneath the salt layer that would range from one to twenty feet thick. All comparisons to Hanford Tank 101-SY would have to be thoroughly investigated and dispositioned. It is assumed that this technical issue can be satisfactorily resolved. This assumption has the most bearing on the viability of IX because it alone enables 3 tanks to be redeployed as salt receivers. If, for technical or safety reasons, this assumption is invalid, then the sludge in these three tanks would have to be removed at a total project and operating cost of about $\$ 20,000,000$ per tank.

Tank 48 is currently the ITP processing tank. If there is no ITP, then Tank 48 could be used to receive salt.

Tank 49 is currently the ITP high activity precipitate stream storage and feed tank. The bulk of the ITP precipitate is nonradioactive potassium. The IX process does not precipitate potassium thus the IX high activity stream will not require as large a tank as will the ITP. It is assumed that Tank 49 will be used for salt receipt and that $\mathrm{X} X$ will build a smaller shielded tank to hold the IX eluate and filter flushes.

If the five tanks identified above as possible salt receivers are used to store salt, then the static material balance becomes:

\section{Tank \\ $30,38,46$}

33

32

35

48

49 $\underline{\text { Notes }}$

form salt above existing HHW sludge, need new $500^{\prime}$ long GDL and associated equipment form salt above existing HHW sludge form salt above existing HHW sludge assume existing precipitate okay as is, need GDL equipment need GDL equipment

Total Salt Space
Available Salt Space (gal)

$2,100,000$ 800,000

900,000 900,000

$1,000,000$

$1,000,000$

$6,700,000$ 


\section{Actions Required to Redeploy Tanks}

Actions required to enable the five additional Type III Tanks to be redeployed as salt receivers are significant and vary by tank as shown below:

Tank 13

- The risk of using Tank 13, a Type II Tank with known leak sites, would have to be analyzed and determined to be acceptable.

- Continued use of Tank 13 would require approval of the Regulator as Tank 13 is scheduled to be removed from active service $1 / 1 / 98$ as a condition of the Tank Farm Wastewater Operating Permit (note: WSRC does not recommend the continued use of Tank 13 in active service - this is discussed only in the "open mind" context of this reevaluation).

- A new feed line to the Replacement High Level Waste Evaporator (RHLWE) would be required to feed the RHLWE while Tank 32 is used as a salt receiver.

Tank 32

- The safety risk of forming saltcake above HHW sludge would have to be developed and determined to be acceptable.

- The funding, design, construction and startup of a Gravity Drain Line to Tank 32 and associated equipment and instruments would have to be added to the RHLWE project.

Tank 33

- The safety risk of forming saltcake above HHW sludge would have to be developed and determined to be acceptable.

- A new 500' long GDL to Tank 33 would have to be designed, constructed and tested on a fast-track basis (the longest GDL in the Tank Farm is about $300^{\prime}$ long so some development and testing may be required).

Tank 35

- The safety risk of forming saltcake above HHW sludge would have to be developed and determined to be acceptable.

- The GDL for Tank 35 on the RHLWE project could not be deferred or deleted from the RHLWE project scope which is being considered at this time. 
Tank 48

- The existing salt precipitate in Tank 48 left over from the ITP demonstration in 1983 would need to be handled at some later date by a process yet to be defined (this would require development work and testing).

- Significant Disassembly and Removal activities would be required to raise slurry pumps and to remove ITP specific equipment and instruments.

- Controls and instrumentation would have to be routed from the ITP Control Room to the $2 \mathrm{H}$ Control Room.

- The existing GDL would have to be refurbished.

- A new GDL backflush valve, containment house, controls and associated service piping would have to be funded, designed, built and tested.

Tank 49

- Significant Disassembly and Removal activities would be required to raise slurry pumps and to remove in-tank equipment and instruments.

- Controls and instrumentation would have to be routed from the ITP Control Room to the $2 \mathrm{H}$ Control Room.

- The existing GDL would have to be refurbished.

- A new GDL backflush valve, containment house, controls and associated service piping would have to be funded, designed, built and tested.

\section{Benzene Abatement}

One potential capital expense associated with the long term operation of ITP and the DWPF Salt Cell is the requirement to reduce benzene emissions. The Clean Air Act of 1990 mandates that benzene emissions be reduced by $95 \%$. The EPA and therefore SCDHEC was given eight years to implement the Act. HLWM has two projects, one for ITP and one for the Salt Cell, prepared to implement the Act at a projected capital cost of $\$ 29,000,000$ plus Other Project Costs associated with startup testing, training, procedures, etc.

The technology for Benzene Abatement is simple and mature. The petroleum industry has extensive experience that is applicable to HLWM. This is not considered to present a programmatic risk to the HLW mission. 


\section{System Status at IX Startup}

If all actions were taken to enable the Tank Farm to wait for IX startup without starting up ITP, then the HLW System would have the following status at the time of IX startup:

- All existing and redeployed salt tanks would be full of salt except for 800,000 gallons of space optimally distributed between the three evaporator systems which would be needed to continue to operate the evaporators during salt removal from the first tank in each evaporator system (see Figure 4).

- The Tank Farm could not support a change in Site mission before or after IX startup for several years such as D\&D, processing of offsite fuels, etc., or the salt inventory would exceed capacity.

- DWPF will have been operating since 1996 on a sludge-only flowsheet at very low attainment at about $\$ 170,000,000$ per year.

- There will possibly be a salt-only flowsheet at the end of the sludge and salt campaign similar in magnitude to the sludge-only campaign.

- The existing and redeployed evaporator salt receipt tanks will be $96 \%$ full of salt and/or concentrated supernate thus the Tank Farm will be virtually "saltbound".

- The $1 \mathrm{H}$ and $2 \mathrm{~F}$ Evaporator systems will have marginal waste receipt capacity with only one staging tank and one feed tank per system and the $2 \mathrm{H}$ system will have just the one feed tank thus the Tank Farm will be 'waterlogged".

- The RHLWE would be using Tank 13 as a feed tank until such time as two salt tanks were emptied in the $2 \mathrm{H}$ Evaporator system, one tank emptied in the $2 \mathrm{~F}$ system and two tanks emptied in the $1 \mathrm{H} / \mathrm{RHLWE}$ system (Tanks 29 and 32) thus Tank 13 will be in active service until about the year 2005 . 
Available Space in Type I Tanks

Using Type I Tanks is often discussed as a method of relieving the Tank Farm waterlog or saltbound condition. There are a total of 12 Type I Tanks: Tanks 1 and 9-12 have a leakage history while Tanks 2-8 are believed to be sound, i.e. there is no evidence of leakage however only a portion of the primary tank wall can be observed. Type I Tanks have a five foot high annulus pan, a maximum capacity of 750,000 gallons and transfer lines with concrete encasements or transite jackets for secondary containment.

WSRC does not recommend that Type I's be considered for use in active service for storing waste. The secondary containment and leak detection capabilities for the tanks and transfer piping do not meet the requirements of the Federal Facilities Agreement, the Resource Conservation and Recovery Act, or the Tank Farm Wastewater Permit. It is also possible that there are inactive leak sites that cannot be observed that could reactivate when dilute waste is added to the tank or transferred through the piping.

Currently, each Tank Farm must maintain equivalent emergency spare capacity in Type III Tanks equal to or greater than the capacity of the largest tank. The possibility exists to use Tanks 2-8 for emergency spare service. The Regulator has written that the Type I Tanks are "approvable" as equivalent emergency spare capacity in lieu of Type III Tanks. Using Tanks 2-8 as emergency spare space would effectively generate 1,300,000 gallons of additional space in Type III Tanks. The available space in sound Type I's is shown in Table 4.

There is about 2,500,000 gallons of available space in the sound Type I Tanks. If $1,300,000$ gallons are reserved for emergency spare space in Tanks 2-6, then about 900,000 gallons of the remaining space remains in Tanks 7 and 8 where storing waste would complicate and delay the preparation of sludge batches \#2 and 3 due to the piping and transfer routes associated with these tanks. Also, the 900,000 gallons of space represents only a few months of DWPF recycle or one sludge batch decant.

Several actions would be required to use Tanks 2-8 as emergency spares. Most importantly, all parties would have to concur that this does not present an unacceptable risk. The safety risk would have to be developed and analyzed. The Tank Farm Safety Analysis Report would have to be revised. Procedure revision and training would have to be completed. Additional jumpers would have to be fabricated and maintained.

For the purposes of this re-evaluation, it is assumed that the Tanks 2-8 are approved for emergency spare service but not for active service. 


\section{Program Risks}

The IX option is not without considerable risk, both technical and programmatic. Significant risks are listed below:

- The decision to fill three of the five fresh HHW receivers with salt precludes SRS from conducting any production missions in the Canyons beyond the Stabilization Programs as currently planned. Fresh HHW must, in general, be aged at least one year in the waste tanks before evaporation. The sludge temperature increases during this storage period and it must be maintained below the boiling point of the liquid waste and below a total heat output of 3,000,000 Btu per hour per tank. This invariably means that two fresh HHW receipt tanks are required to support normal Canyon operations. If both Canyons are operating, then at least four tanks must be in fresh HHW receipt service. Maintaining one HHW receiver in each area would support some Canyon HHW processing.

- Any significant Canyon or Reactor D\&D program could not be supported by the Tank Farm until well after 2005.

- There must be a favorable safety determination that forming salt above HHW sludge does not present an unacceptable risk. Again, this is a most crucial assumption.

- Waiting for LX to start up without starting up ITP drives the Tank Farm to a condition where every available tank that could store salt is used for salt storage is virtually at capacity.

- The decision to fill three of the five fresh HHW receivers with salt reduces the staging capacity of each evaporator system. Currently, the $1 \mathrm{H}$ system uses Tanks 32,35 and 39 to receive, age and store HHW prior to transferring to Tank 13 , the $1 \mathrm{H}$ Evaporator feed tank. The $2 \mathrm{~F}$ system used Tanks 33 and 34 to receive, age and store waste prior to transferring to Tank 26, the $2 \mathrm{~F}$ Evaporator feed tank. The HHW staging tanks serve to decouple the Tank Farm from the daily operation of the Canyons. If Tanks 32, 33 and 35 are used for salt, then the "wide spot" upstream of the evaporators is largely eliminated. This becomes crucial considering that sludge removal decants will be about 600,000 gallons each, ESP aluminum dissolution batches will be about 900,000 gallons each and routine ESP washwater batches will be about 350,000 gallons each. In addition, the DWPF will send 147,000 to 300,000 gallons per month of recycle water. Under the IX scenario, the receipt space must always be maintained in the evaporator feed tanks which will be very difficult to ensure as the sludge inventory in Tanks 26 and 43 will continue to increase thus reducing the working capacity in 
those two feed tanks. This means that there will be ESP attainment losses while waiting for the evaporators to recover enough space to accept the ESP washwater decants. In fact, this is the current situation in the H-Area Tank Farm that is delaying the completion of the ESP Process Verification Test by several months.

- There is virtually no contingency to compensate for error on the following:

- DWPF recycle rate

- DWPF recycle salt content

- Canyon waste forecast

- Canyon waste stream salt content

- Abnormal evaporator downtime

- IX inability to reach planned capacity or attainment

- Variability in salt soundings used to determine the current inventory of salt in the Tank Farm

- variability in sludge sample results used to determine the soluble and insoluble content in sludge before washing

- There is a significant risk that LX would not be funded adequately to achieve radioactive operations at the planned date thus further delaying waste removal from old-style tanks.

- Significant concessions would be needed from the Regulator for continued use of Tank 13 as the $1 \mathrm{H}$ Evaporator/RHLWE feed tank and for further delays in the resumption of waste removal from old-style tanks.

- The IX flowsheet and process development is not complete. While there is a high degree of confidence in the IX unit operation, there is significant development work yet to be done on the physical characteristics of the resin, resin handling, resin process lifetime, and feed/product stream logistics and transfer facilities.

- The Tank Farm would not be able to support the future unevaporated waste stream from the 211-F Canyon Outside facilities after the currently planned Stabilization program is complete and the Canyon is shut down. This could represent an additional cost to the DP or EM program of $\$ 16,000,000$ to $\$ 40,000,000$ for needed facility upgrades as already proposed by Separations personnel.

- The disposition of the existing salt precipitate from the 1983 ITP Demonstration must be successfully developed and tested. 


\section{Further Evaluation of IX as a 1st generation ITP Replacement}

If the decision is made to continue to pursue $\mathrm{LX}$ as a 1 st generation ITP replacement, then a comprehensive in-depth evaluation and development program is recommended. The program remains the same as described in previous work at a total cost of about $\$ 18,000,000$ and a total duration of 39 months. Design of an IX facility could start concurrently with the second phase of the proposed development program (IDMS runs) depending on the acceptable degree of risk. The program should have key decision points (go / no go decisions) relative to ITP, Late Wash and Precipitate Hydrolysis to ensure that available funding is conserved.

\section{Summary}

We strongly recommend that salt processing continue as currently planned. While the gap between ITP and IX has narrowed some since the last evaluation, we feel that the current course of action is the most cost effective, most environmentally responsible and most flexible option for the Site. While IX appears to be a viable alternative to ITP, we cannot recommend the IX option at this time due to the significant programmatic risk inherent in that program. If $\mathrm{IX}$ is to be pursued as a first generation ITP replacement, then we recommend the rapid formation of a team and funding strategy to implement the previously proposed comprehensive process development program with key "go / no go" decision points relative to ITP, Late Wash and Precipitate Hydrolysis. 


\section{References}

1. Letter, A. B. Scott, Jr. to S. D. Richardson, High Level Waste System Plan, Revision 1, HLW-VP-93-0007, August 5, 1993.

2. Letter, N. C. Boyter to L. C. Sjostrom, WSRC Evaluation of Ion Exchange as a Pretreatment Process for DWPF, WER-VP-92-0133, September 15, 1992.

3. IX Technology Assessment Report, J. M. Pope, E. F. Duhn, et. al., The Implementation of Ion Exchange Technology in the Pretreatment of Soluble HLW Feed to the DWPF, WSRC-RP-92-1093TL, September 15, 1992.

4. Letter, N. C. Boyter to L. C. Sjostrom, Ion Exchange Technology Program, WER-VP-92-0107, July 28, 1992.

5. HLW Engineering Monthly Data Record, July, 1993.

6. Memorandum, T. E. Pate to S. S. Cathey, et. al., FY93 Radioactive Liquid Waste Forecast, WER-CMD-92-0712, December 15, 1992.

7. E. W. Holtzscheiter to D. B. Amerine, Material Balance Tables for the DWPF Radioactive Runs with Batch 1 Sludge/Supernate Feed, WSRC92-0211-TL, November 9, 1992.

8. FY95 Five Year Plan.

9. Production and Planning Directive 93-0.

10. ASD-NMP-93-0009, revision 2, April 22, 1993.

11. Memorandum, B. Subramani to N. R. Davis, Waste Routing in F-Tank Farm, WER-WRP-93-0044, June 21, 1993. 


\section{Table 1 - DOE-SR Assumptions}

Assumption

1. In-Tank Precipitation will not be available and salt

decontamination will be done

exclusively using IX

Existing structures ... will be used for IX to the maximum possible extent

3. Known techniques for manipulating the radioactivity of resins ... are to be used

4. IX implementation can be done within the scope of an existing project or the best possible alternate path should be identified ...

5. IX implementation will be coordinated to meet the earliest startup date for DWPF while maximizing retention of Tank Farm space

6. Additional research and development should be minimized and accelerated to the extent possible
Interpretation

- ITP, Late Wash and the DWPF Salt Cell will not go "hot" and therefore be more easily retrofitted for IX

- There will be no additional CsTPB precipitate to process beyond the amount currently stored in Tank 48

- Salt removal must wait until IX is operational

- every effort should be made to house IX unit operations in existing facilities such as ITP, Late Wash and the DWPF Salt Cell

- the cost of IX should be minimized as much as possible

- the re-evaluation should not propose extensive new development programs if a workable technology exists

- $R \& D$ costs should be minimized

- a fast-track approach similar to Late Wash should be used

- if a new project is needed, then every possible method to accelerate the project should be explored

- significant delays to the startup of DWPF as a result of IX are unacceptable

- the IX approach must be such that the Tank Farm does not become "saltbound" or "waterlogged"

- similar to assumption \# 3 


\section{Table < - WSRC Assumptions}

1. There will be no new waste tanks built at SRS.

2. - The existing Site missions will be supported, i.e. removing waste from tanks and the Separations Phaseout and Stabilization programs.

3. - There will be no new Site missions, such as Canyon or Reactor D\&D or Separations processing of offsite fuels, that generate significantly more waste than what is currently forecast.

4. - The Canyons will continue to evaporate miscellaneous streams after the Phaseout and Stabilization programs are complete until such time as HLWM can assume this additional load, i.e. until the RHLWE starts up.
- There is a historical agreement with the US Government that no new waste tanks will be built after the approval of the DWPF project.

- Building new waste tanks costing an estimated $\$ 80,000,000$ each (based on a recent waste tank project at Idaho) does not comply with DOE-SR guidance for a timely and economical IX program.

- All Site missions are included in the Liquid Waste Forecast and are therefore part of this study. Those missions will not be delayed due to lack of space in the Tank Farm.

- This study does not conservatively assume that the Tank Farm will reserve space in case one of the currently proposed or conceptual missions becomes a reality. All available Tank Farm space will be used to support the existing Site mission and to enable the Tank Farm to support IX.

- Separations plans to shut down all operations after the Phaseout and Stabilization programs are complete, however, some evaporation operations must continue until the RHLWE comes on line. 


\section{Table < - WSRC Assumptions}

5. - DWPF will start up on sludgeonly and continue to operate at low attainment until IX is ready to be tied-in.

6. Sludge batch\#2 will be washed before IX starts up to enable the feed to DWPF to be continuous.

7. - Sludge and salt precipitate operations will start when sludge batch\#2 is ready to feed to DWPF.

8. - Tanks 2-8 (sound Type I Tanks) can be used as $1.3 \mathrm{Mgal}$ of emergency spare space for the FArea Tank Farm in lieu of space in Type III Tanks.

9. - IX most be reasonably "decoupled" from the Tank Farm and DWPF similar to ITP and ESP as they currently exist
- Salt processing will not be possible until IX comes on line. The quickest way to start up DWPF. is to start up on a sludge-only feed stream.

- The cost of maintaining a qualified work force at DWPF is about $\$ 170 \mathrm{M} / \mathrm{yr}$ whether DWPF runs or not, therefore, it is assumed that DWPF will continue to operate vs shut down to wait for IX.

- It is too costly to idle the DWPF for two years while sludge batch\#2 is washed.

- DWPF will consume sludge batch\#1 in a sludge-only campaign, go down to convert to sludge and salt precipitate operations, and then restart on sludge batch\#2 and salt precipitate.

- The Regulator has indicated that this option is "approvable" which effectively generates $1,300,000$ gallons of additional tank space in Type III Tanks vs current operating practice.

- It is not feasible to feed IX continuously or in small batches directly from salt tanks in F-Area. There also needs to be sufficient tankage to store the IX product such that IX does not have to shut down every time that a downstream facility shuts down. 


\section{Table S - Type III Tank Usage Matrix}

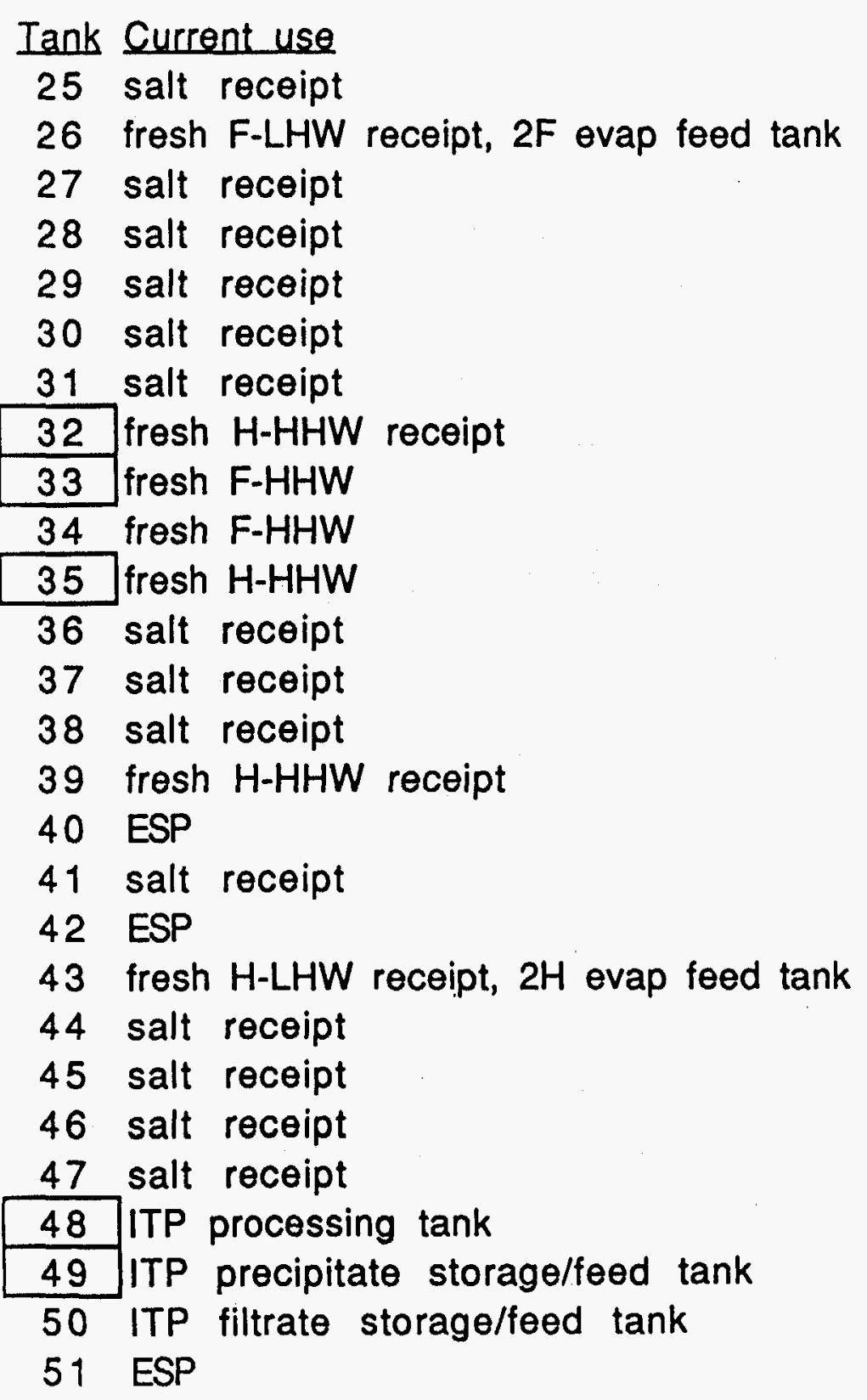

Notes/Future Use

full of salt now, will refill

2F Evaporator feed tank

full of salt/high $\mathrm{sp}$ gr supernate

full of salt now, will refill

full of salt now, will refill

filling with salt, will be full by $8 / 97$

full of salt now, will refill

could be used for salt from $1 \mathrm{H}$ if not used for $1 \mathrm{H}$ feed tank could be used for salt from $2 F$ if no new mission

leave as only fresh F-HHW receiver

could be used for salt from $1 \mathrm{H}$ if no new mission

full of salt now

full of salt now

filling, will be full $11 / 95$

leave as only fresh $\mathrm{H}$-HHW receiver

ESP processing tank

full of salt now

ESP processing tank

$2 \mathrm{H}$ Evaporator feed tank

full of salt now

full of salt now

fill with salt upon $2 F$ restart, will be full by $6 / 99$

full of salt, also $248 \mathrm{kgal}$ sludge

could fill with salt, use as 1 st IX feed, IX feed thereafter could be used for salt if IX builds eluate tank

keep as ETF receipt tank and Saltstone feed tank

ESP processing tank 


\section{Table 4 - Available Space in Type I Ianks}

$\begin{array}{rrrrl}\text { Tank } & \begin{array}{r}\text { Level } \\ \text { (inches) }\end{array} & \begin{array}{r}\text { Limit [1] } \\ \text { (inches) }\end{array} & \begin{array}{r}\text { Available } \\ \text { Space [2] } \\ \text { (gallens) }\end{array} & \begin{array}{l}\text { When } \\ \text { Available? }\end{array} \\ 2 & 199 & 218 & 51,490 & \text { now } \\ 3 & 199 & 208 & 24,390 & \text { now } \\ 4 & 195 & 263 & 184,280 & \text { now } \\ 5 & 13 & 264 & 680,210 & \text { now } \\ 6 & 9 & 265 & 693,760 & \text { now } \\ 7 & 141 & 265 & 336,040 & {[3]} \\ 8 & 61 & 261 & 542,000 & \text { after sludge removal for sludge batch\#2 } \\ & & & & \\ & & \text { Total } & 2,512,170 & \text { (1,634,130 gallons of space available now) }\end{array}$

Notes

[1] The operating limit is a function of the specific gravity of the tank contents, i.e. as the specific gravity increases, the allowable tank operating limit decreases.

[2] The tank calibration is 2,710 gallons/inch. Available Space in gallons is the operating limit minus the level times 2,710 .

[3] Tanks 1-3 are piped to transfer into Tank 7 from which transfers to other parts of the $F$ and H-Tank Farm are possible. Tank 7 should store no other waste until Tanks 1-3 are emptied. Tank 7 could then be considered for other uses although this is not recommended. 


\section{Figure 1 - Flow Diagram of Proposed IX Process}

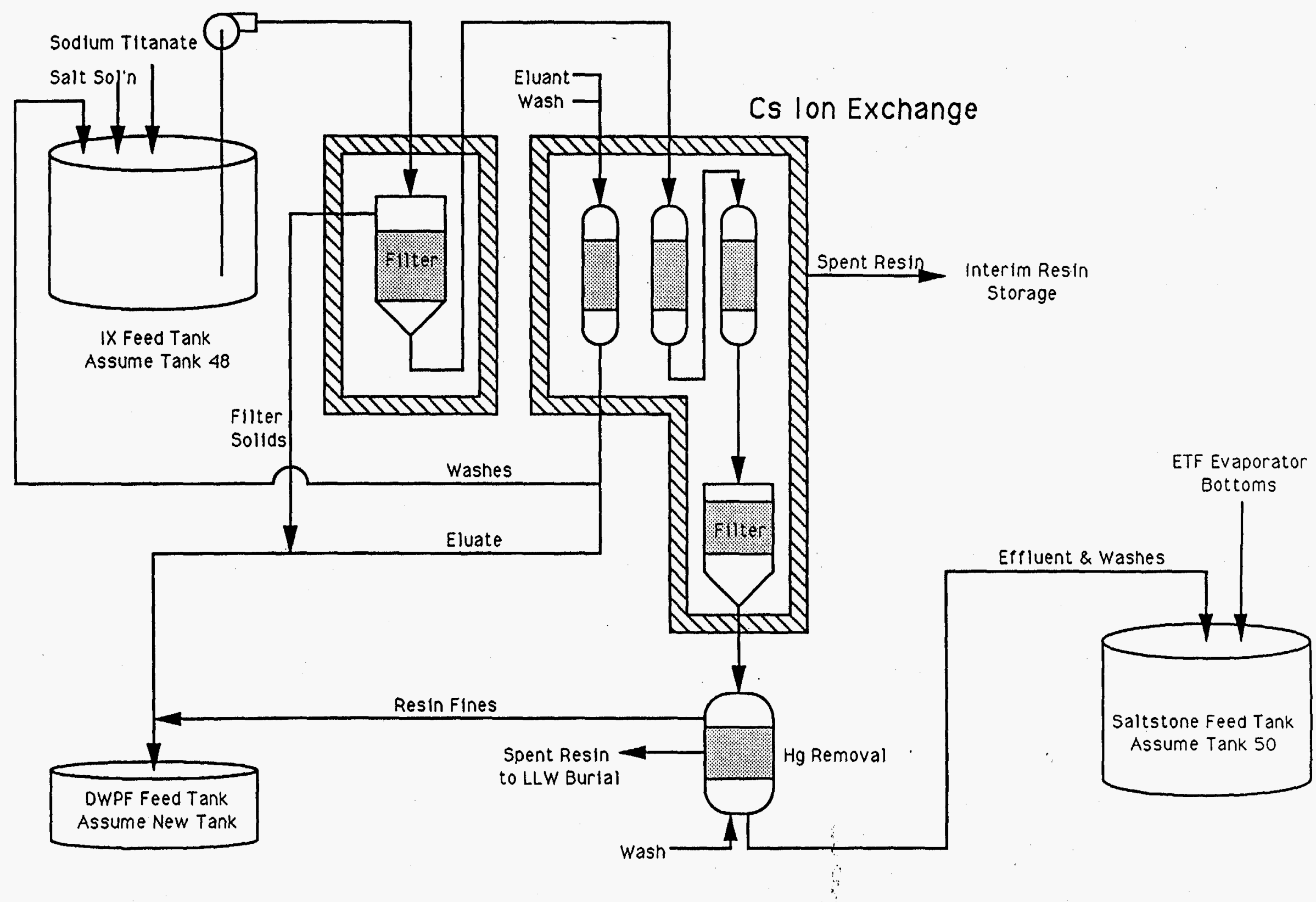




\section{Figure 2 - IX Salt Processing}

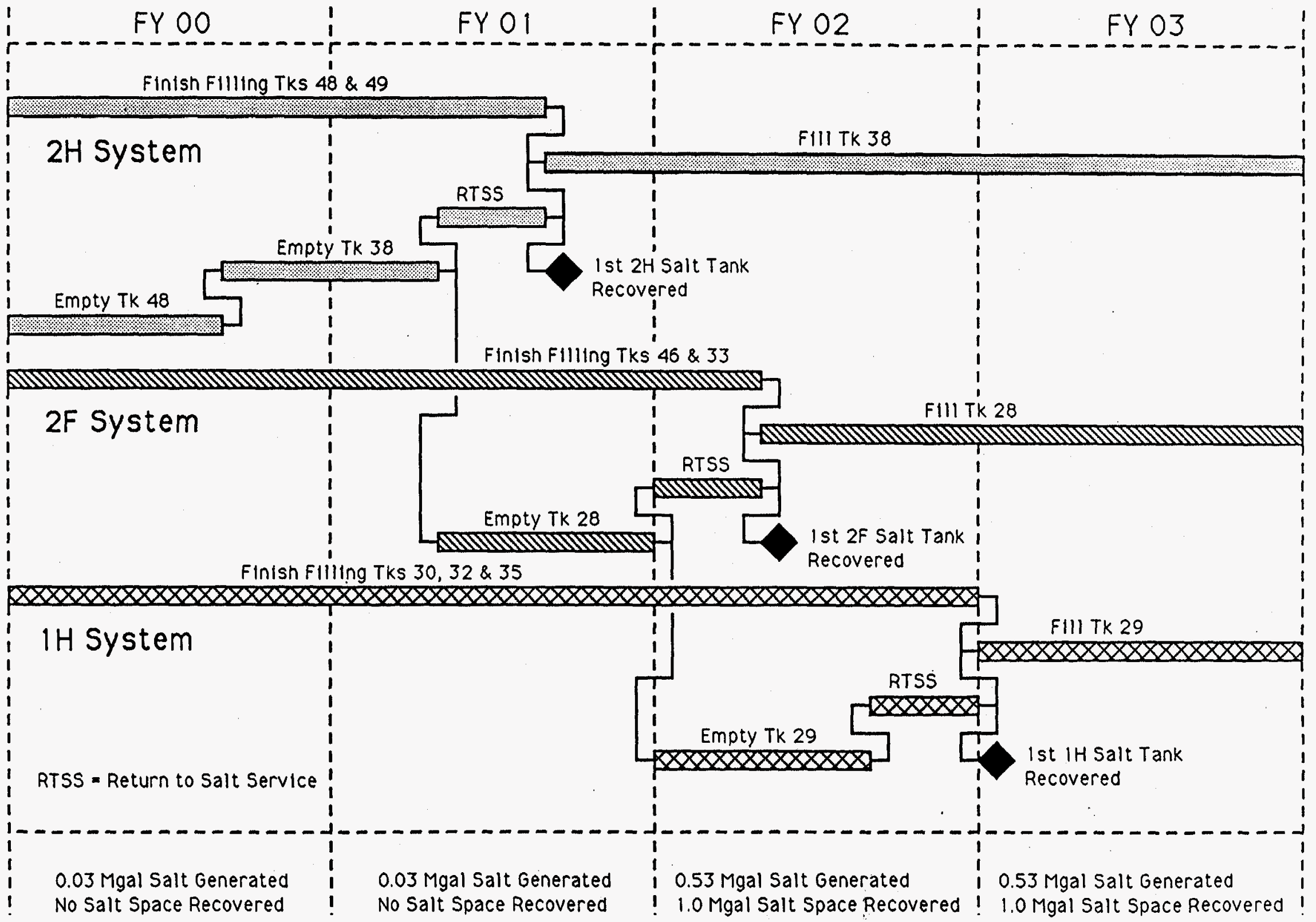

